Article

\title{
Uncovering the Topic Landscape of Product-Service System Research: from Sustainability to Value Creation
}

\author{
Hakyeon Lee, Hanbin Seo and Youngjung Geum * \\ Department of Industrial and Systems Engineering, Seoul National University of Science and Technology, \\ Seoul 01811, Korea; hylee@seoultech.ac.kr (H.L.); myhb9188@seoultech.ac.kr (H.S.) \\ * Correspondence: yjgeum@seoultech.ac.kr; Tel.: +82-2-970-6528
}

Received: 21 February 2018; Accepted: 19 March 2018; Published: 21 March 2018

check for updates

\begin{abstract}
As the product-service system (PSS) is considered a promising business model that can create more value for customers, PSS research has enjoyed remarkable growth in its volume and coverage over the last decade. This study aims to delineate the thematic landscape of PSS research by identifying latent topics from a large amount of scholarly data. Ten topics of PSS research are identified by applying the Latent Dirichlet Allocation (LDA) model to 1229 PSS publications published between 2000 and 2016. The ten PSS topics are briefly reviewed to provide an overview of what has previously been studied in PSS research. We also investigate which topics rise or fall in popularity by identifying hot and cold topics of PSS research. It is observed that the focus of discussions on the benefits of PSS has shifted from sustainability to value creation. Also, increasing attention has been paid to more practical topics such as PSS implementation. The areas of subspecialty of the top ten PSS journals are also examined to explore the interdisciplinary nature of PSS research and thematic differences across disciplines. The findings of this study can provide rich implications for both academia and practice in the field of PSS.
\end{abstract}

Keywords: product service system (PSS); servitization; topic modeling; Latent Dirichlet Allocation (LDA)

\section{Introduction}

The integration of products and services has become increasingly prevalent in recent years. The product-service system (PSS), initially aimed to facilitate sustainable growth by reducing environmental impacts, is now considered a promising business model that can create more value for customers in today's competitive business environment [1,2]. The growing perception of PSS as an effective means for enhancing a firm's competitiveness in practice has also boosted academic research efforts into PSS from a variety of perspectives such as definitions, classifications, benefits, barriers, methodologies, and tools [3].

There has been a surge in the number of excellent review papers on PSS as the overall body of literature on this has rapidly grown. It is common for scholars to pay attention to the literature itself once a knowledge domain reaches a certain degree of maturity [4]. Many efforts have been made to systematically review the literature on PSS to grasp what has previously been achieved and provide directions for future research [3,5-9], but their specific objectives differ somewhat. Some reviews aim to summarize and report the findings of previous studies along with three or four broad categories of topics $[3,5,8]$. Other reviews intend to examine the thematic structure of PSS research by classifying the relevant articles into several pre-defined topics. For example, Annarelli et al. [9] explored the conceptual structure of PSS research by assigning 224 articles into six main focus and 10 main topic groups. Boehm and Thomas [7] investigated the multidisciplinary characteristics of PSS research by classifying 265 references from three different disciplines into 19 topics. 
What topics are explored and/or which topics are popular in PSS research are useful pieces of information for researchers, but the approach adopted in the previous reviews, that is, discrete assignments with predetermined categories, has some weakness. First, the subjective and manual allocations based on abstracts or keywords are accompanied by the risk of classification error. The amount of time required may be the reason only around two hundred of the papers were considered in the previous reviews. Second, predetermined categories may not be exhaustive, and authors may not be aware of relatively new and emerging topics in the field. Thirdly, an article usually contains two or more topics, thus labeling an article under a single topic does not make sense. A prerequisite for thorough and systematic review of the literature is therefore to empirically identify latent topics from a large amount of scholarly data and use fractional assignment to measure their proportions. The topic modeling approach is a promising solution to these problems. Topic models are algorithms used to automatically discover the latent topics prevalent within a large and unstructured collection of documents [10]. They do not require any prior labeling of documents and therefore can be analyzed independent of human judgment. Fractional assignments are made by assuming that documents exhibit multiple topics that can subsequently be modeled as probability distributions. Due to these advantages, in recent years there have been many applications of topic modeling to identify topics in a specific academic domain [11].

This study aims to delineate the thematic landscape of PSS research by identifying its latent topics using topic modeling. Specifically, the Latent Dirichlet Allocation (LDA) model, currently the most popular topic modeling algorithm, is employed to uncover latent topics from 1229 articles on PSS research. We then briefly review each topic to provide an overview of about twenty years of PSS research. We also investigate which topics are rising or falling in popularity by identifying hot and cold topics of PSS research. The top 10 journals are also identified in terms of the number of PSS articles published, and their areas of subspecialty are also examined and compared.

The remainder of this paper is organized as follows. Section 2 provides a brief review of the topic model approach and its applications for identification of research topics. The data and methods used for identifying topics are explained in Section 3. Section 4 provides the thematic landscape of PSS research based on the results of topic modeling. Finally, the conclusions are provided in Section 5, along with limitations and directions for future research.

\section{Topic Modeling With LDA}

Topic modeling employs statistical algorithms to uncover the main themes permeating a large collection of texts [10,12]. It is assumed that a document is a mixture of topics, and a topic is characterized as a probability distribution over words. The aim of topic models is thus to estimate both topic distribution per document and word distribution per topic from the observed words in actual documents [10]. Topic models have been successfully utilized for a variety of text mining tasks due to their advantages including principled mathematical foundations for document generation mechanism and an automated process not requiring prior labeling of documents [11].

LDA is the most widely used algorithm of topic modeling. It can estimate the mixture of existing topics in newly given documents without updating the current model. High volumes of documents can be handled in LDA because it has a fixed number of parameters regardless of the corpus size [13]. The basic idea of LDA is that documents are expressed as random mixtures over latent topics, each of which is characterized by a distribution over words. Figure 1 represents the document generation process of LDA where nodes represent random variables. The shaded node, $w_{d, i}$ indicating the $i$ th word in the $d$ th document, is only observable whereas the other nodes are hidden. The document generation process of LDA is as the following: (1) per-topic word distributions $\left(\phi_{k}\right)$ are estimated for the whole corpus; (2) per-document topic proportions $\left(\theta_{d}\right)$ are determined; (3) each word is chosen based on the topic assigned $\left(z_{d, i}\right)$. In Figure $1, \alpha$ and $\beta$ are the Dirichlet hyper-parameters for $\theta_{d}$ and $\phi_{k}$, respectively. $N$ denotes the number of words in a document, $D$ indicates the number of documents in 
a corpus, and $K$ is the number of topics across the corpus, respectively. For more technical information on LDA including training and inference, see Blei et al. [13].

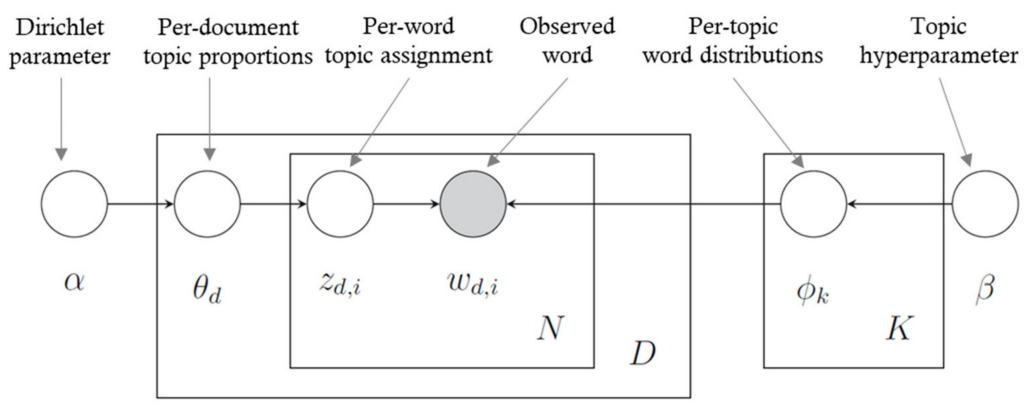

Figure 1. Document generation process of LDA [13].

LDA applications used for identification of research topics in a knowledge domain, for example, statistics [14], biology [15], bioinformatics [16], information science [17], computer science [18], and technology management [11], have seen a huge increase in recent years. Those studies demonstrated the usefulness of LDA in identifying research topics from a large set of publications of a knowledge domain. This paper also employs the LDA model for identifying latent topics in PSS research.

\section{Identifying PSS Topics}

\subsection{Data Collection}

The articles of PSS research were collected from SCOPUS, which is one of the largest databases of academic publications covering a wide range of multidisciplinary journals and proceedings. SCOPUS was also used in the recent reviews of PSS [5,6,9]. We extracted articles including the keywords "product service system" in their titles, abstracts or keywords section. It was confirmed that "product service system" and "product-service system" generated the same set of publications. The document type was limited to article, article in press, review, conference paper, and book chapter. The publication period was restricted to between 2000 and 2016 because very few articles on PSS were published before 2000. An initial set of 1269 documents were obtained from the keyword search, and by excluding those documents whose abstract is not available, a total of 1229 articles were produced as the dataset for this study. The database includes basic the bibliometric information of the articles such as titles, authors, journals, and publication year, abstracts, and references.

Figure 2 depicts the annual changes in the number of PSS articles. It is shown that the volume of PSS research has grown continuously from only one articles in 2000 to 216 articles in 2016, although a slight decrease was observed in 2016. It seems that the PSS research has reached its mature stage. Table 1 shows top 10 sources including journals and proceedings by PSS publications. No big difference is observed in the list of top 10 sources when comparing the statistics of Tukker [5].

Table 1. Number of PSS publications for top 10 sources.

\begin{tabular}{ccc}
\hline Rank & Source & Counts \\
\hline 1 & Journal of Cleaner Production & 70 \\
2 & IFIP Advances in Information and Communication Technology & 43 \\
3 & Proceedings of the International Conference on Engineering Design & 39 \\
4 & Proceedings of the ASME Design Engineering Technical Conference & 23 \\
5 & CIRP Journal of Manufacturing Science and Technology & 22 \\
6 & Journal of Manufacturing Technology Management & 21 \\
7 & Lecture Notes in Computer Science & 21 \\
8 & International Journal of Production Research & 20 \\
9 & Computers in Industry & 14 \\
9 & International Journal of Advanced Manufacturing Technology & 14 \\
\hline
\end{tabular}




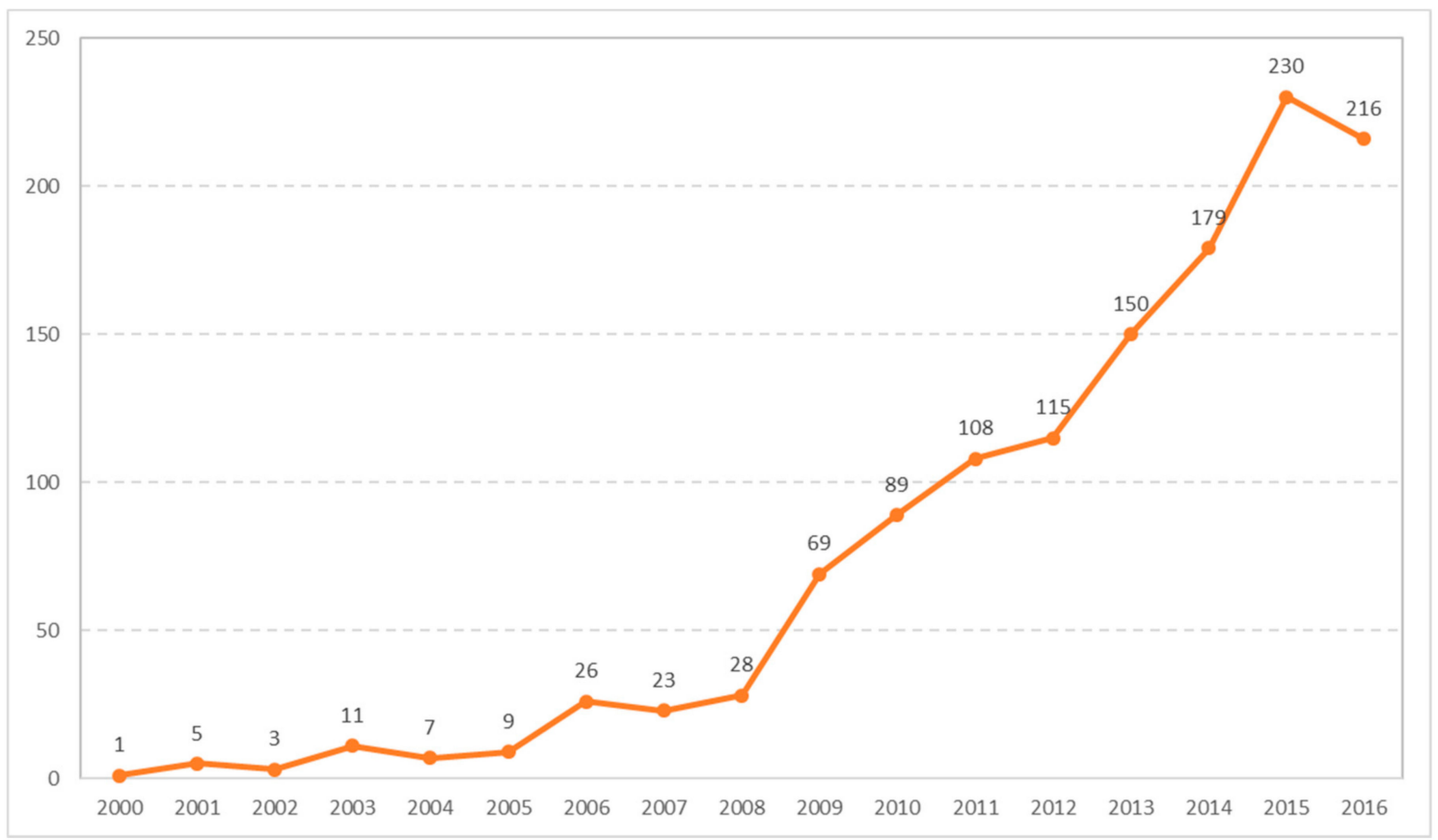

Figure 2. Annual changes in the number of PSS publications.

\subsection{Preprocessing and LDA Inference}

The corpus of the analysis is composed of 1229 abstracts of the collected articles. Before conducting the LDA inference, the texts of the corpus were passed through a series of pre-processing steps. Firstly, all punctuation and numbers were removed, and all uppercase letters were transformed into lower-case. Secondly, tokenization was performed to break a sentence into several words. Thirdly, all stop-words including articles ( $\mathrm{a}$, an, the), prepositions, and pronouns were eliminated. In addition, we also removed several user-defined stop-words that frequently appear in the abstracts of academic articles, such as "paper," "study," "show," and "discuss". Fourthly, we conducted the lemmatization process to find the lemma of each word. A word can take various forms to comply with grammatical rules, and therefore words should be replaced by their lemmas to reduce dimensionality without loss of generality. For example, the word servitize may be used as a verb form of either servitize, servitizes, and servitized, or it can be used as either servitization or servitizations. Lemmatization will replace servitize, servitizes, and servitized with servitize, also servitization or servitizations with servitization. Lastly, each document was transformed into the bag-of-words representation. If the corpus includes $N$ words after stop-words removal and lemmatization, each abstract is represented by an $\mathrm{N}$-dimensional vector in which the value of an element is the frequency of the corresponding word in the abstract.

We then fitted the LDA model using the R package, "topicmodels" [19]. The collapsed Gibbs sampling method was used to estimate the LDA parameters with 1000 iterations. For Dirichlet parameters, $\alpha$ was estimated based on the corpus and $\beta$ is set to the default value, 0.1 . One of the most important variables to be determined for the LDA inference is the number of topics, $K$. A quantitative performance measure, such as perplexity, can be gauged and referred for determining the number of topics. For qualitative analysis, it is commonly determined by domain experts to have more interpretable topics [20]. We closely investigated the per-topic word distributions for three different values of $K, 5,10$, and 20 , and finally decided to use 10 topics.

\subsection{Topic Labelling}

The derived topics were then labeled by an expert group composed of five professors with more than five years' experience of researching PSS. Basically, topics are labeled by referring their frequent 
words which display high probability. However, designating a topic solely based on the list of frequent words is by no means straightforward because a word itself may not be indicative of the topic. For more effective labeling, the experts were provided with the abstracts of the 20 most relevant articles with high loadings for each topic.

Each expert was asked to define the 10 topics with their own labels prior to the workshop. The workshop was then held to collect individual labeling results and confirm the final labels of the 10 topics. The five experts proposed identical or similar labels for seven topics, and different labels for the other three topics. After an in-depth discussion, the expert group finally reached a consensus on the labels of the three topics, (T4), (T9), and (T10). Finally, the 10 topics of PSS research were defined as shown in Table 2. Topics were numbered in descending order of their proportion in the whole corpus. For each topic, ten relevant word lemmas are provided with its share.

Table 2. Topics of PSS research.

\begin{tabular}{|c|c|c|}
\hline Topic & Relevant words & Share \\
\hline (T1) PSS concepts & $\begin{array}{l}\text { service, product, system, manufacturing, integrate, } \\
\text { integrated, enterprise, paradigm, traditional, trend }\end{array}$ & 0.1048 \\
\hline (T2) Industrial PSS & $\begin{array}{l}\text { process, industrial, ips2, development, lifecycle, } \\
\text { knowledge, system, support, engineering, solution, }\end{array}$ & 0.1024 \\
\hline $\begin{array}{l}\text { (T3) PSS as business model } \\
\text { for value creation }\end{array}$ & $\begin{array}{l}\text { model, business, customer, company, value, offer, } \\
\text { relationship, creation, market, benefit }\end{array}$ & 0.1014 \\
\hline (T4) PSS implementation & $\begin{array}{l}\text { pss, methodology, implementation, framework, case, } \\
\text { factor, field, barrier, context, literature }\end{array}$ & 0.1012 \\
\hline $\begin{array}{l}\text { (T5) Servitization of } \\
\text { manufacturing }\end{array}$ & $\begin{array}{l}\text { servitization, innovation, manufacture, industry, strategy, } \\
\text { firm, practice, transformation, challenge, transition }\end{array}$ & 0.1002 \\
\hline $\begin{array}{l}\text { (T6) PSS as means of } \\
\text { sustainability }\end{array}$ & $\begin{array}{l}\text { sustainable, sustainability, environmental, impact, } \\
\text { consumption, energy, social, eco, resource, material }\end{array}$ & 0.0996 \\
\hline (T7) PSS design & $\begin{array}{l}\text { design, method, concept, new, activity, tool, function, } \\
\text { project, feature, designer }\end{array}$ & 0.0994 \\
\hline $\begin{array}{l}\text { (T8) PSS as solution to } \\
\text { customer requirements }\end{array}$ & $\begin{array}{l}\text { requirement, customer, system, solution, problem, } \\
\text { component, domain, need, software, integrated }\end{array}$ & 0.0982 \\
\hline (T9) PSS evaluation & $\begin{array}{l}\text { cost, performance, decision, evaluation, quality, time, risk, } \\
\text { evaluate, method, simulation }\end{array}$ & 0.0968 \\
\hline (T10) PSS with ICT & $\begin{array}{l}\text { system, information, technology, data, user, need, } \\
\text { communication, ICT, application, smart }\end{array}$ & 0.0960 \\
\hline
\end{tabular}

\section{Review of PSS topics}

The ten topics presented in Table 2 make up the thematic landscape of PSS research. The ten topics can be grouped into several categories. Some of them relate to the basic concepts and trends of PSS, e.g., (T1) PSS concepts, (T2) Industrial PSS, and (T5) Servitization of manufacturing. Some topics deal with roles and benefits of PSS, namely, (T3) PSS as business model for value creation, (T6) PSS as means of sustainability, and (T8) PSS as solution to customer requirements. Other topics cover a series of critical tasks of PSS development: (T4) PSS implementation, (T9) PSS evaluation, and (T7) PSS design, and together with the roles of ICT in PSS development, (T10) PSS with ICT. It is worthwhile to compare the ten topics with the components of the review frameworks of previous reviews. Table 3 shows the components used in the four general review articles on PSS and their corresponding topics. It is shown that some of the topics have never been considered in previous review and some of them are more specified than the components of previous reviews. For example, (T10) PSS with ICT is not dealt with in any of the four articles, and benefits or advantages of PSS are specified as three topics, (T3), (T6), and (T8). The ten topics are collectively exhaustive sets of PSS research themes. Reviewing the ten topics can thus provide a quick overview of what has been studied in PSS research. A brief review 
of each topic is provided hereafter with some references. The topics are presented and reviewed in a semantic order, not in the order of topic numbers.

Table 3. Components of review frameworks in previous reviews and their corresponding topics.

\begin{tabular}{|c|c|c|c|c|}
\hline Topic & Annarelli et al. [9] & Baines et al. [8] & Beuren et al. [3] & Tukker [5] \\
\hline (T1) PSS concepts & Definition of PSS & $\begin{array}{l}\text { Definition of } \\
\text { PSS, Evolution of } \\
\text { PSS concept, } \\
\text { Features of PSS }\end{array}$ & $\begin{array}{c}\text { Definitions of PSS, } \\
\text { Classification } \\
\text { of PSS }\end{array}$ & PSS concept \\
\hline (T2) Industrial PSS & - & - & - & - \\
\hline $\begin{array}{c}\text { (T3) PSS as } \\
\text { business model for } \\
\text { value creation }\end{array}$ & PSS benefits & Benefits of PSS & $\begin{array}{c}\text { Benefits and } \\
\text { barriers of PSS }\end{array}$ & $\begin{array}{c}\text { Business and } \\
\text { environmental } \\
\text { advantages of PSS }\end{array}$ \\
\hline $\begin{array}{c}\text { (T4) PSS } \\
\text { implementation }\end{array}$ & $\begin{array}{l}\text { PSS barriers, } \\
\text { PSS drivers }\end{array}$ & $\begin{array}{c}\text { Barriers to } \\
\text { adoption of PSS, } \\
\text { Applications of PSS }\end{array}$ & $\begin{array}{c}\text { Benefits and } \\
\text { barriers of PSS }\end{array}$ & - \\
\hline $\begin{array}{l}\text { (T5) Servitization } \\
\text { of manufacturing }\end{array}$ & - & $\begin{array}{l}\text { Evolution of } \\
\text { PSS concept }\end{array}$ & - & PSS concept \\
\hline $\begin{array}{l}\text { (T6) PSS as means } \\
\text { of sustainability }\end{array}$ & PSS benefits & Benefits of PSS & $\begin{array}{c}\text { Benefits and } \\
\text { barriers of PSS }\end{array}$ & $\begin{array}{c}\text { Business and } \\
\text { environmental } \\
\text { advantages of PSS }\end{array}$ \\
\hline (T7) PSS design & - & $\begin{array}{c}\text { Tools and } \\
\text { methodologies for } \\
\text { designing PSS }\end{array}$ & $\begin{array}{l}\text { PSS design } \\
\text { methodologies }\end{array}$ & - \\
\hline $\begin{array}{l}\text { (T8) PSS as solution } \\
\text { to customer } \\
\text { requirements }\end{array}$ & PSS benefits & Benefits of PSS & $\begin{array}{c}\text { Benefits and } \\
\text { barriers of PSS }\end{array}$ & $\begin{array}{c}\text { Business and } \\
\text { environmental } \\
\text { advantages of PSS }\end{array}$ \\
\hline (T9) PSS evaluation & - & - & - & - \\
\hline (T10) PSS with ICT & - & - & - & - \\
\hline
\end{tabular}

Once a promising new concept has emerged, it is common practice for scholars to concentrate on developing common grounds for advanced research. Accordingly, (T1) PSS concepts is found to be the most extensively studied topic. Including Goedkoop et al. [21] which first proposed the term PSS as "a marketable set of products and services capable of jointly fulfilling a user's need", earlier studies focused on clearly framing the PSS concept including its definitions and characteristics. Annarelli et al. [9] identified six common aspects of PSS definition by reviewing 19 definitions given in PSS studies, and found that "system concept" and "market proposition/customer needs" are the main features of PSS that are included in most of the PSS definitions while "effect on environment" is not frequently considered. Boehm and Thomas [7] compared various PSS definitions from three disciplines: information systems, business management, and engineering design. It should be noted that the concept of product-service integration has not been solely discussed under the term of PSS. Park et al. [22] reviewed 13 concepts relevant to integration of products and services including PSS, and insisted that there are no big differences among those concepts except the distinction between marketing-oriented concepts and engineering-oriented ones.

The concept of PSS can also be understood under the paradigm shift toward (T5) Servitization of manufacturing, although the two bodies of research have developed separately. PSS can be viewed as an outcome of servitization [8]; or servitization can be defined as the shift from selling product to selling PSS [23]. Since Vandermerwe and Rada [24] first coined the term, servitization, it has attracted much attention from various research communities including service marketing, service management, operations management, service science as well as product-service system [25]. Various industrial examples for different types of servitization strategy have been reported through case study 
e.g., [26]. Much effort has also been devoted to drawing managerial implications including drivers to pursue a servitization strategy e.g., [27], success factors of servitization e.g., [28], and challenges in the adoption of servitization e.g., [29].

The notion of (T2) Industrial PSS (industrial product-service system: IPS2) is also closely related with servitization of manufacturing. IPS2 applies only in business-to-business applications and is characterized by a life-cycle oriented integration of the industrial supply of products and service parts [30]. It is distinct from PSS in that the integrated development of the mutually determined product and service shares is essential for IPS2 [31]. Earlier works attempted to develop the basic frameworks of IPS including definitions and business models, and recent studies have tackled various aspects of IPS2 such as organization e.g., [32], development e.g., [33], implementation e.g., [34], and evaluation e.g., [35]. It should be noted that the "IPS" abbreviation has been used to indicate similar but slightly different concepts in the literature: industrial product-service system (IPS2) [30], integrated product and service offerings (IPSO) [2], and integrated product-service (IPS) [22].

In the early stages of PSS research, much emphasis was imposed on (T6) PSS as means of sustainability because PSS is expected to have a lower environmental impact than traditional business models [21]. In fact, one of the antecedents of PSS is the concept of eco-efficient producer service (EEPS) which refers to "a product-service mix which has a higher added value and a smaller environmental impact". Some researchers have insisted that the ultimate goal of adding services to traditional products lies in the achievement of sustainability [36]. Sustainability can be achieved through the transition towards the functional economy in which customers purchase "dematerialized" functions instead of physical products [37], where "dematerialization" refers to the opportunity offered by PSS to break the link between value offered to customers and the physical materials required to create the value [8]. Earlier studies thus focused on using case studies for the exploration of the environmental benefits of different PSS types [5].

However, recent years have witnessed a remarkable shift in discussions on the main benefits of PSS, from sustainability to value creation-(T3) PSS as business model for value creation. The PSS business model provides more additional values than the traditional business model of product sales by adding services to existing products [38]. As a result, customers can obtain added value through more and higher quality customized offers [1]. It seems that a consensus has been reached in relation to specific types of PSS business model: product-oriented PSS in which a provider delivers a service related to the product, use-oriented PSS in which the usability of the product or service is provided, and result-oriented PSS in which a provider delivers an outcome [39]. The three distinct business models differ in terms of value delivery and capture as well as value creation [6]. Much effort has been devoted to the modeling of PSS business models that are able to maximize customer values through customization and co-creation e.g., [40].

PSS creates values by solving customers' specific problems [41]. In other words, PSS can be viewed as a "solution" to what customers want-(T8) PSS as integrated solution to customer requirements. Since offering stand-alone products can no longer meet complex and rapidly-changing customer needs, manufacturing firms are changing their strategy from product-centric to customer-centric by offering an integrated solution, which is a bundle of hardware, software, and services necessary to solve specific problems of customers [42]. A complete understanding of what customers wants is a requisite for customizing the best solutions, thus increasing attention has been paid to engineering requirements for PSS [43]. Although only a little progress has been made in this direction, integrated approaches to PSS requirements engineering are expected to be further developed by integrating models and methods of requirements engineering of product-, software-, and service-engineering [44].

PSS requirements engineering provides critical inputs to (T7) PSS design. Since PSS are complex systems composed of various product and service elements, PSS design requires a more systematic approach from the system perspective [45]. Existing tools and methodologies for product or service design may potentially contribute to PSS design, but they should be modified or extended to reflect such unique features of PSS design [46]. Various tools, techniques, and methods have been employed 
in PSS design, and Qu et al. [47] classified them into six types: customer perspective, modeling techniques, visualization methods, modularity, TRIZ, and system dynamics. Much effort has also been devoted to developing frameworks and methodologies which are tailored to PSS design such as the life-cycle oriented framework [48], the service engineering framework [49], the customization-oriented framework [50], a step-by-step approach to design for sustainability [51], methodology for PSS innovation [52], and PSS design methodology [45].

What follows the stage of PSS design is (T9) PSS evaluation, more specifically, evaluation of PSS design alternatives. When multiple designs are generated, they need to be comparatively evaluated so that the best alternative can be chosen. If a single design exists, its feasibility and validity should be measured prior to implementation. As the two main benefits of PSS are sustainability and value creation for customers, PSS evaluation has also been approached from the two perspectives, customer values and sustainability [47]. Customer values have often been measured in terms of customer satisfaction or service quality [53]. Early studies on measuring sustainability were centered on the environmental perspective e.g., [54], while recent studies embrace multiple dimensions of sustainability by adopting the triple-bottom-line framework composed of social, economic, and environmental dimensions e.g., [55]. In terms of evaluation methods, the conventional methods used for design evaluation of products and services have been also employed in the evaluation of PSS designs such as multiple-criteria decision-making techniques, for example the analytic hierarchy process e.g., [56], simulation techniques such as system dynamics e.g., [55], and economic analysis including net present value e.g., [57].

A good PSS design does not guarantee its business success. It should be well implemented through effective plans and strategies-(T4) PSS implementation. A variety of case studies on PSS have been conducted to draw implications for successful PSS implementation, including its barriers and tactics [8]. When it comes to barriers to adoption of PSS, most studies have recognized the cultural shift as the main shift [9], since buying and selling functions instead of physical products is a significant change for both producers and customers [58]. Lack of knowledge and resources such as technological information, experience in service design, and skilled service development personnel in are also important barriers to adoption of PSS [59]. Successful PSS implementation requires effective tactics because they determine how much value is created and captured. Reim et al. [6] identified various tactics for the three different business models of PSS from the literature review and classified them into five distinct sets: contracts, marketing, network, design, and sustainability.

ICTs can boost value creation in the process of PSS implementation; often PSS cannot be implemented without ICT [60]. Much attention has been paid to the role and effect of ICT on PSS-(T10) PSS with ICT. The role of technology has long been a matter of interest in the service literature, for example the reverse cycle model [61] and the technology infusion matrix in service encounters [62]. Now the focus has shifted from service to PSS, particularly, the role and influence of ICT on PSS. The rapid advance of ICT has made many types of PSS more economic and practical [37]. Several attempts have been made to classify the different roles of ICT in integrating products and services. For example, Lelah and Brissaud [63] proposed the following five different configurations between ICT and PSS: product pre-equipped with ICT, distinct ICT and product, ICT monitoring product, mutualized ICT infrastructure, and ICT support network. Geum et al. [64] identified the three types of roles for technology as an enabler, a mediator, and a facilitator for integrating products and services. Several studies were more specific in their examination of how to incorporate particular ICTs in the design and implementation of PSS, such as wearable technology [65] and Internet of Things [66].

\section{Trends in PSS Topics}

\subsection{Topic Proportions Over Time}

Examining the dynamic change of PSS topics over time in terms of their proportion enables us to grasp the overall trend in PSS research. Increasing topic proportion indicates that the topic 
is an emerging area of research, whereas decreasing topic proportion would imply the opposite. We investigated whether each topic rises or falls in popularity by employing regression analysis. A simple linear regression model was built for each topic with the year index being the input variable and the topic proportions in the corresponding years being the response variable [67]. The ten topics were then categorized into four types based on results of regression including the sign of the slope and its statistical significance: hot (cold) topics whose slopes are positive (negative) at a statistical significance level of 0.05 and warm (cool) topics whose slope are positive (negative) but not statistically significant.

Accordingly, six hot topics, one cold topic, and three cool topics were identified as shown in Table 4, and no warm topic was found. Figure 3 represents the proportion changes of the ten topics over time. A noticeable finding is that (T6) PSS as means of sustainability is the only cold topic. Its proportion exceeds $20 \%$ in the early 2000 s but has shown a dramatic drop to below $10 \%$. This empirically confirms the assertion made in the recent review: "PSS started its development linked to sustainability, but nowadays it is no longer the most influential aspect in PSS research [9]." Although this does not indicate that PSS no longer contributes to sustainability, it seems obvious that sustainability is no longer central to discussions of PSS.

Table 4. Regression results and topic types.

\begin{tabular}{cccc}
\hline Topic & Slope ${ }^{*}{ }^{* 1000)}$ & $p$-Value & Type \\
\hline (T1) PSS concepts & -1.3049 & 0.1227 & COOL \\
(T2) Industrial PSS & 2.1015 & 0.0110 & HOT \\
(T3) PSS as business model for value creation & 2.2890 & 0.0008 & HOT \\
(T4) PSS implementation & 2.6195 & 0.0000 & HOT \\
(T5) Servitization of manufacturing & 1.7787 & 0.0015 & HOT \\
(T6) PSS as means of sustainability & -8.9856 & 0.0000 & COLD \\
(T7) PSS design & -0.7380 & 0.3631 & COOL \\
(T8) PSS as solution to customer requirements & -1.2642 & 0.1468 & COOL \\
(T9) PSS evaluation & 1.4264 & 0.0214 & HOT \\
(T10) PSS with ICT & 2.0776 & 0.0000 & HOT \\
\hline
\end{tabular}

The emphasis has shifted to (T3) PSS as business model for value creation, which is the second hottest topic. PSS is now perceived as a new business model that can create more value for customers, and thus also provides new opportunities to increase the revenues of manufacturers. It seems that manufactures have become increasingly aware of the benefits of PSS as a new business model given that (T5) Servitization of manufacturing and (T2) Industrial PSS are also identified as hot topics. In the meantime, it is observed that (T4) PSS implementation is the hottest topic with the sharpest slope, and (T10) PSS with ICT also has a highly positive slope. This indicates that PSS has moved away from conceptual academic discussions and has been widely been adopted in industry practice. While earlier studies were devoted to clarifying the concepts of PSS and discussing its benefits in academia, the focus of research has now been moved to how to implement PSS business in real practice. 

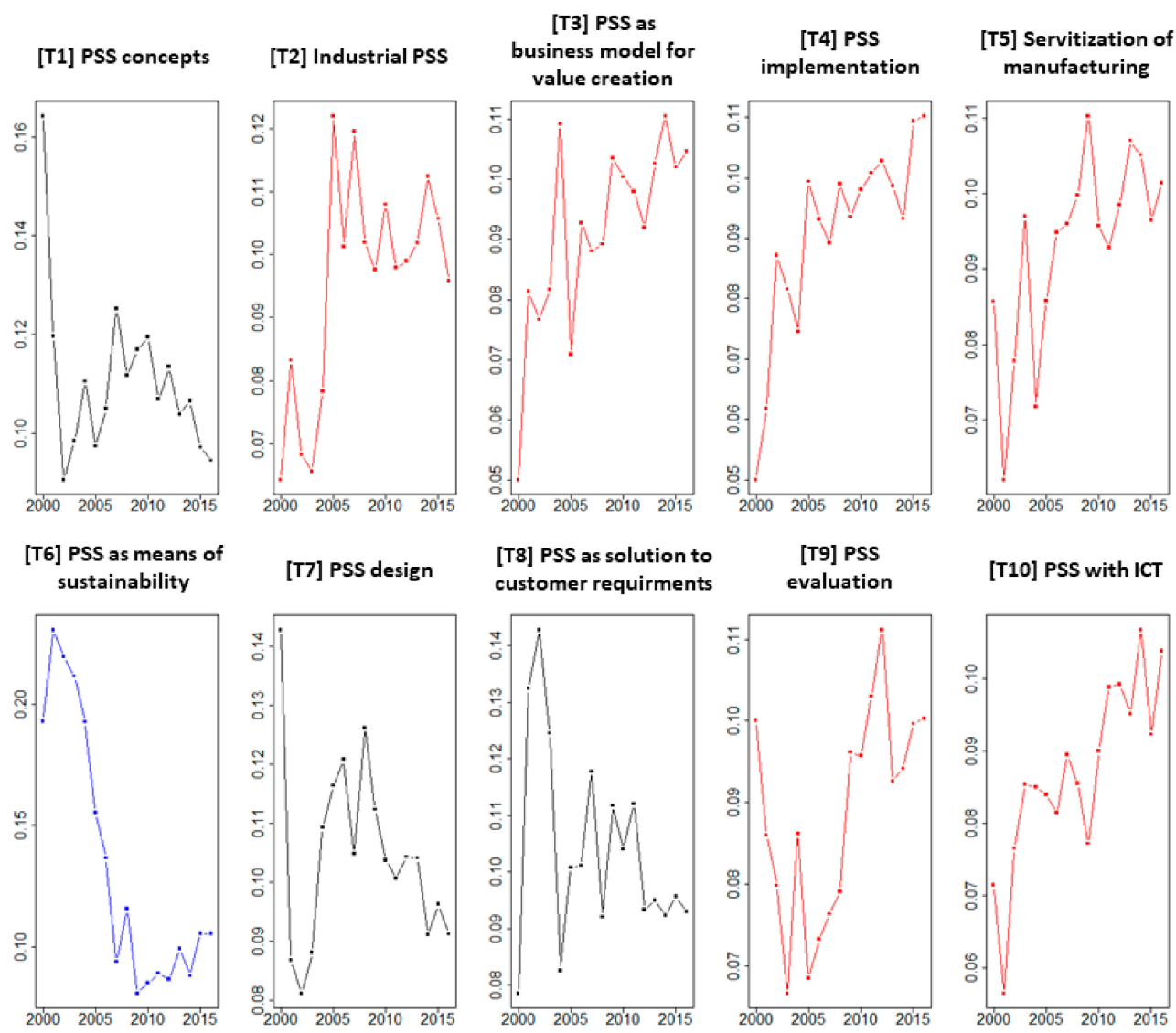

[T10] PSS with ICT


Figure 3. Hot (red), Cold (blue), and Warm (gray) topics and their proportion changes over time.

\subsection{Topic Proportions Across Journals}

PSS research is an interdisciplinary field. Various disciplines such as business management, engineering design, and information systems have contributed to the PSS research [7]. The interdisciplinary nature of PSS research is also well illustrated by Table 1 providing a list of the top ten journals of PSS research. These ten journals have different origins and coverage and each journal has its own interests and scopes. Although the journals commonly deal with PSS, the focus may differ across journals. To examine such thematic differences, Table 5 provides the composition ratio of the ten topics covered by each journal. The top two topics for each journal are highlighted in bold.

The composition of topic portfolios of the ten journals clearly demonstrate their unique aims and scope. The largest number in Table 4 is $18.56 \%$ of (T6) PSS as means of sustainability for The Journal of Cleaner Production. Since one of the main subject areas of The Journal of Cleaner Production is sustainable development and sustainability, it is not surprising that about one-fifth of its contents are devoted to the topic of sustainability. The top ten list involves the two sources devoted to engineering design, Proceedings of the International Conference on Engineering Design and Proceedings of the ASME Design Engineering Technical Conference, and the most popular topic for both sources is (T7) PSS design. IFIP Advances in Information and Communication Technology does not demonstrate much interest in (T10) PSS with ICT, even though ICT is included in its name. Lecture Notes in Computer Science put the greatest emphasis on the topic of ICT. The composition of topic portfolios of the four manufacturing journals are significantly different, but it is shown that (T5) Servitization of manufacturing and (T4) PSS implementation are commonly popular topics for manufacturing journals. Such good matching between topic composition and journals' interests may indicate that published contents are well fitted to journals' editorial policies and scope. From the reverse perspective, however, it can also indicate that the topics obtained from LDA accurately capture what has been done in PSS research. 
Table 5. Topic compositions of top ten sources (the row sums equal to 1).

\begin{tabular}{|c|c|c|c|c|c|c|c|c|c|c|}
\hline Source Title & $\begin{array}{c}\text { (T1) } \\
\text { PSS } \\
\text { Concepts }\end{array}$ & $\begin{array}{c}\text { (T2) } \\
\text { Industrial } \\
\text { PSS }\end{array}$ & $\begin{array}{c}\text { (T3) } \\
\text { PSS as } \\
\text { Business } \\
\text { Model for } \\
\text { Value Creation }\end{array}$ & $\begin{array}{c}\text { (T4) } \\
\text { PSS } \\
\text { Implementation }\end{array}$ & $\begin{array}{c}\text { (T5) } \\
\text { Servitization of } \\
\text { Manufacturing }\end{array}$ & $\begin{array}{c}\text { (T6) } \\
\text { PSS as } \\
\text { Means of } \\
\text { Sustainability }\end{array}$ & $\begin{array}{l}\text { (T7) } \\
\text { PSS Design }\end{array}$ & $\begin{array}{c}\text { (T8) } \\
\text { PSS as } \\
\text { Solution to } \\
\text { Customer } \\
\text { Requirements }\end{array}$ & $\begin{array}{c}\text { (T9) } \\
\text { PSS } \\
\text { Evaluation }\end{array}$ & $\begin{array}{l}\text { (T10) } \\
\text { PSS with } \\
\text { ICT }\end{array}$ \\
\hline Journal of Cleaner Production & $8.52 \%$ & $8.25 \%$ & $9.05 \%$ & $10.96 \%$ & $10.85 \%$ & $18.56 \%$ & $8.99 \%$ & $8.82 \%$ & $7.29 \%$ & $8.72 \%$ \\
\hline $\begin{array}{l}\text { IFIP Advances in Information and } \\
\text { Communication Technology }\end{array}$ & $12.17 \%$ & $11.84 \%$ & $10.72 \%$ & $10.26 \%$ & $10.34 \%$ & $9.11 \%$ & $7.96 \%$ & $9.16 \%$ & $8.70 \%$ & $9.73 \%$ \\
\hline $\begin{array}{l}\text { Proceedings of the International } \\
\text { Conference on Engineering Design }\end{array}$ & $9.52 \%$ & $10.05 \%$ & $9.73 \%$ & $11.86 \%$ & $9.26 \%$ & $7.21 \%$ & $14.98 \%$ & $8.94 \%$ & $7.43 \%$ & $11.02 \%$ \\
\hline $\begin{array}{l}\text { Proceedings of the ASME Design } \\
\text { Engineering Technical Conference }\end{array}$ & $11.46 \%$ & $7.69 \%$ & $10.74 \%$ & $10.60 \%$ & $6.65 \%$ & $7.63 \%$ & $16.00 \%$ & $12.35 \%$ & $9.41 \%$ & $7.46 \%$ \\
\hline $\begin{array}{l}\text { CIRP Journal of Manufacturing } \\
\text { Science and Technology }\end{array}$ & $13.47 \%$ & $10.69 \%$ & $11.22 \%$ & $11.56 \%$ & $10.42 \%$ & $8.27 \%$ & $9.27 \%$ & $8.85 \%$ & $8.15 \%$ & $8.11 \%$ \\
\hline $\begin{array}{c}\text { Journal of Manufacturing Technology } \\
\text { Management }\end{array}$ & $7.06 \%$ & $8.96 \%$ & $10.54 \%$ & $14.09 \%$ & $16.84 \%$ & $6.40 \%$ & $8.92 \%$ & $9.17 \%$ & $11.50 \%$ & $6.53 \%$ \\
\hline Lecture Notes in Computer Science & $10.15 \%$ & $9.15 \%$ & $8.14 \%$ & $7.97 \%$ & $10.37 \%$ & $10.35 \%$ & $13.01 \%$ & $9.11 \%$ & $7.14 \%$ & $14.62 \%$ \\
\hline $\begin{array}{c}\text { International Journal of Production } \\
\text { Research }\end{array}$ & $11.66 \%$ & $9.69 \%$ & $10.81 \%$ & $8.36 \%$ & $11.84 \%$ & $8.46 \%$ & $7.03 \%$ & $10.99 \%$ & $12.57 \%$ & $8.60 \%$ \\
\hline Computers in Industry & $12.47 \%$ & $9.58 \%$ & $8.75 \%$ & $10.79 \%$ & $6.96 \%$ & $6.38 \%$ & $11.53 \%$ & $12.81 \%$ & $11.04 \%$ & $9.69 \%$ \\
\hline $\begin{array}{l}\text { International Journal of Advanced } \\
\text { Manufacturing Technology }\end{array}$ & $10.83 \%$ & $9.01 \%$ & $10.48 \%$ & $9.67 \%$ & $7.93 \%$ & $7.26 \%$ & $10.03 \%$ & $9.69 \%$ & $13.97 \%$ & $11.13 \%$ \\
\hline
\end{tabular}




\section{Conclusions}

This study delineated the thematic landscape of PSS research by identifying its top ten topics through LDA topic modeling. These topics were then briefly reviewed to provide an overview of previous PSS studies. We also investigated which topics rise or fall in popularity by identifying hot and cold topics of PSS research. It was observed that the focus of discussions on PSS benefits has shifted from sustainability to value creation. Increasing attentions has also been paid to more practical topics such as implementation of PSS, away from conceptual discussions in academia. The areas of subspecialty of the top ten PSS journals were also examined to explore the interdisciplinary nature of PSS research and thematic differences across disciplines.

PSS research has enjoyed a remarkable growth in its volume and coverage over the last decade, therefore it is considered imperative to grasp and share what has been achieved in PSS research to ensure its continued progress. In response, many attempts have been made to systematically review the PSS literature, but those reviews depended on authors' own judgement when developing the review framework. This paper reviewed the PSS literature based on the ten topics automatically uncovered by LDA from a large amount of PSS publications. However, it should be noted that the whole procedure of identifying topics is not fully objective. LDA automatically discover latent topics independent of human judgment but labeling them requires human judgment. The findings of this study can provide rich implications for both academia and practice in the field of PSS. Researchers can judge whether their research topics of interest are rising and falling and can be guided in setting future research directions. Journal editors can confirm whether past publications of PSS coincide with editorial policy. Designers and engineers may encounter useful references that can aid the development and implementation of PSS.

Nevertheless, this study is also subject to several limitations which could serve as avenues for further research. First, PSS is not the only concept dealing with integration of products and services. The notion of product-service integration has been studied under various terms from various disciplines, for example, full service, product service, solution, and functional sales [22]. Nevertheless, we only used "product service system" for our keyword search to limit the scope of literature analysis to only PSS concepts. This led to exclusion of important publications that have some relation to PSS from the dataset, in particular, those from the field of business management in which the term, PSS, is not rarely used. If various keywords are used for publication searches, richer discussions about the phenomenon of product-service integration can be made from various perspectives. Second, we examined the trends as a whole, but the popularity of each topic may differ across countries or regions. Also, different industry sectors of PSS may have different preferences to topics. Examining the trends by countries or sectors and comparing the differences can also deliver useful implications.

Acknowledgments: This work was supported by the National Research Foundation of Korea (NRF) Grant funded by the Korea government (MSIP) (NRF-2017R1E1A1A01077324).

Author Contributions: Hakyeon Lee developed the research framework; Hanbin Seo collected, handled, and analyzed the data; Youngjung Geum and Hakyeon Lee conducted the literature review and wrote the manuscript; All the authors have read and approved the manuscript.

Conflicts of Interest: There is no conflict of interest.

\section{References}

1. Mont, O.K. Clarifying the concept of product-service system. J. Clean. Prod. 2002, 10, 237-245. [CrossRef]

2. Lindahl, M.; Sundin, E.; Öhrwall Rönnbäck, A.; Öhlund Sandström, G.; Östlin, J. Integrated product and service engineering-the ipse project. In Proceedings of the Workshop of the Sustainable Consumption Reasearch Exchange (SCORE!), Linköpings universitet, Copenhagen, Denmark, 20-21 April 2006.

3. Beuren, F.H.; Gomes Ferreira, M.G.; Cauchick Miguel, P.A. Product-service systems: A literature review on integrated products and services. J. Clean. Prod. 2013, 47, 222-231. [CrossRef] 
4. Ramos-Rodríguez, A.R.; Ruíz-Navarro, J. Changes in the intellectual structure of strategic management research: A bibliometric study of the strategic management journal, 1980-2000. Strateg. Manag. J. 2004, 25, 981-1004. [CrossRef]

5. Tukker, A. Product services for a resource-efficient and circular economy-A review. J. Clean. Prod. 2015, 97, 76-91. [CrossRef]

6. Reim, W.; Parida, V.; Örtqvist, D. Product-service systems (pss) business models and tactics-A systematic literature review. J. Clean. Prod. 2015, 97, 61-75. [CrossRef]

7. Boehm, M.; Thomas, O. Looking beyond the rim of one's teacup: A multidisciplinary literature review of product-service systems in information systems, business management, and engineering \& design. J. Clen. Prod. 2013, 51, 245-260.

8. Baines, T.S.; Lightfoot, H.W.; Evans, S.; Neely, A.; Greenough, R.; Peppard, J.; Roy, R.; Shehab, E.; Braganza, A.; Tiwari, A. State-of-the-art in product-service systems. Proc. Inst. Mech. Eng. Part B: J. Eng. Manuf. 2007, 221, 1543-1552. [CrossRef]

9. Annarelli, A.; Battistella, C.; Nonino, F. Product service system: A conceptual framework from a systematic review. J. Clean. Prod. 2016, 139, 1011-1032. [CrossRef]

10. Blei, D.M. Probabilistic topic models. Commun. ACM 2012, 55, 77-84. [CrossRef]

11. Lee, H.; Kang, P. Identifying core topics in technology and innovation management studies: A topic model approach. J. Technol. Transf. 2018, 1-27, in press. [CrossRef]

12. Zhang, L.; Liu, B. Aspect and entity extraction from opinion documents. In Data Mining and Knowledge Discover for Big Data: Methodologies, Challenge and Opportunities; Chu, W.W., Ed.; Springer: Los Angeles, CA, USA, 2014; pp. 1-40.

13. Blei, D.M.; Ng, A.Y.; Jordan, M.I. Latent dirichlet allocation. J. Mach. Learn. Res. 2003, 3, 993-1022.

14. De Battisti, F.; Ferrara, A.; Salini, S. A decade of research in statistics: A topic model approach. Scientometrics 2015, 103, 413-433. [CrossRef]

15. Wang, H.; Ding, Y.; Tang, J.; Dong, X.; He, B.; Qiu, J.; Wild, D.J. Finding complex biological relationships in recent pubmed articles using bio-lda. PLOS one 2011, 6, e17243. [CrossRef] [PubMed]

16. Song, M.; Kim, S.Y. Detecting the knowledge structure of bioinformatics by mining full-text collections. Scientometrics 2013, 96, 183-201. [CrossRef]

17. Yan, E. Research dynamics: Measuring the continuity and popularity of research topics. J. Informetr. 2014, 8, 98-110. [CrossRef]

18. He, B.; Ding, Y.; Tang, J.; Reguramalingam, V.; Bollen, J. Mining diversity subgraph in multidisciplinary scientific collaboration networks: A meso perspective. J. Informetr. 2013, 7, 117-128. [CrossRef]

19. Hornik, K.; Grün, B. Topicmodels: An r package for fitting topic models. J. Stat. Softw. 2011, 40, 1-30.

20. Andrzejewski, D.; Mulhern, A.; Liblit, B.; Zhu, X. Statistical debugging using latent topic models. In Proceedings of the 18th European Conference on Machine Learning, Warsaw, Poland, 17-21 September 2007; Springer: Berlin/Heidelberg, Germany, 2007; pp. 6-17.

21. Goedkoop, M.J.; Van Halen, C.J.; Te Riele, H.R.; Rommens, P.J. Product service systems, ecological and economic basics. Report for Dutch Ministries of environment (VROM) and economic affairs (EZ) 1999, 36, 1-122. Available online: http:/ / teclim.ufba.br/jsf/indicadores/holan\%20Product $\% 20$ Service\%20Systems \% 20main\%20report.pdf (accessed on 21 March 2018).

22. Park, Y.; Geum, Y.; Lee, H. Toward integration of products and services: Taxonomy and typology. J. Eng. Technol. Manag. 2012, 29, 528-545. [CrossRef]

23. Baines, T.S.; Lightfoot, H.W.; Benedettini, O.; Kay, J.M. The servitization of manufacturing: A review of literature and reflection on future challenges. J. Manuf. Technol. Manag. 2009, 20, 547-567. [CrossRef]

24. Vandermerwe, S.; Rada, J. Servitization of business: Adding value by adding services. Eur. Manag. J. 1988, 6, 314-324. [CrossRef]

25. Lightfoot, H.; Baines, T.; Smart, P. The servitization of manufacturing: A systematic literature review of interdependent trends. Int. J. Op. Prod. Manag. 2013, 33, 1408-1434. [CrossRef]

26. Sawhney, M.; Balasubramanian, S.; Krishnan, V.V. Creating growth with services. MIT Sloan Manag. Rev. 2004, 45, 34.

27. Oliva, R.; Kallenberg, R. Managing the transition from products to services. Int. J. Serv. Ind. Manag. 2003, 14, 160-172. [CrossRef] 
28. Gebauer, H.; Friedli, T.; Fleisch, E. Success factors for achieving high service revenues in manufacturing companies. Benchmarking: Int. J. 2006, 13, 374-386. [CrossRef]

29. Brax, S. A manufacturer becoming service provider-challenges and a paradox. Manag. Serv. Qual.: Int. J. 2005, 15, 142-155. [CrossRef]

30. Meier, H.; Uhlmann, E.; Kortmann, D. Hybride Leistungsbündel-Nutzenorientiertes Produktverständnis Durch Interferierende Sach-und Dienstleistungen. Available online: https:/ /www.werkstattstechnik.de/wt/ article.php?data\%5barticle_id\%5d=2367 (accessed on 21 March 2018).

31. Meier, H.; Völker, O.; Funke, B. Industrial product-service systems (ips2). Int. J. Adv. Manuf. Technol. 2011, 52, 1175-1191. [CrossRef]

32. Meier, H.; Uhlmann, E.; Krug, C.; Völker, O.; Geisert, C.; Stelzer, C. Dynamic ips 2 networks and operations based on software agents. CIRP J. Manuf. Sci. Technol. 2010, 3, 165-173. [CrossRef]

33. Nguyen, H.N.; Exner, K.; Schnürmacher, C.; Stark, R. Operationalizing ips2 development process: A method for realizing ips2 developments based on process-based project planning. Procedia CIRP 2014, 16, $217-222$. [CrossRef]

34. Uhlmann, E.; Raue, N.; Gabriel, C. Flexible implementation of ips2 through a service-based automation approach. Procedia CIRP 2013, 11, 108-113. [CrossRef]

35. Lagemann, H.; Dorka, T.; Meier, H. Evaluation of an ips2 delivery planning approach in industry—Limitations and necessary adaptations. Procedia CIRP 2014, 16, 187-192. [CrossRef]

36. Manzini, E.; Vezzoli, C.; Clark, G. Product-service systems: Using an existing concept as a new approach to sustainability. J. Des. Res. 2001, 1, 27-40. [CrossRef]

37. Roy, R. Sustainable product-service systems. Futures 2000, 32, 289-299. [CrossRef]

38. Nasiri, M.; Rantala, T.; Saunila, M.; Ukko, J.; Rantanen, H. Transition towards sustainable solutions: Product, service, technology, and business model. Sustainability 2018, 10, 358. [CrossRef]

39. Tukker, A. Eight types of product-service system: Eight ways to sustainability? Experiences from suspronet. Bus. Strategy Environ. 2004, 13, 246-260. [CrossRef]

40. Zine, P.U.; Kulkarni, M.S.; Chawla, R.; Ray, A.K. A framework for value co-creation through customization and personalization in the context of machine tool pss. Procedia CIRP 2014, 16, 32-37. [CrossRef]

41. Kim, S.; Son, C.; Yoon, B.; Park, Y. Development of an innovation model based on a service-oriented product service system (pss). Sustainability 2015, 7, 14427-14449. [CrossRef]

42. Galbraith, J.R. Organizing to deliver solutions. Org. Dyn. 2002, 31, 194-207. [CrossRef]

43. Berkovich, M.; Leimeister, J.M.; Krcmar, H. Requirements engineering for product service systems. Bus. Inf. Sys. Eng. 2011, 3, 369-380. [CrossRef]

44. Berkovich, M.; Leimeister, J.M.; Hoffmann, A.; Krcmar, H. A requirements data model for product service systems. Requir. Eng. 2014, 19, 161-186. [CrossRef]

45. Maussang, N.; Zwolinski, P.; Brissaud, D. Product-service system design methodology: From the pss architecture design to the products specifications. J. Eng. Des. 2009, 20, 349-366. [CrossRef]

46. Baxter, D.; Roy, R.; Doultsinou, A.; Gao, J.; Kalta, M. A knowledge management framework to support product-service systems design. Int. J. Comput. Integr. Manuf. 2009, 22, 1073-1088. [CrossRef]

47. Qu, M.; Yu, S.; Chen, D.; Chu, J.; Tian, B. State-of-the-art of design, evaluation, and operation methodologies in product service systems. Comput. Ind. 2016, 77, 1-14. [CrossRef]

48. Aurich, J.C.; Fuchs, C.; Wagenknecht, C. Life cycle oriented design of technical product-service systems. J. Clean. Prod. 2006, 14, 1480-1494. [CrossRef]

49. Pezzotta, G.; Pirola, F.; Pinto, R.; Akasaka, F.; Shimomura, Y. A service engineering framework to design and assess an integrated product-service. Mechatronics 2015, 31, 169-179. [CrossRef]

50. Song, W.; Sakao, T. A customization-oriented framework for design of sustainable product/service system. J. Clean. Prod. 2017, 140, 1672-1685. [CrossRef]

51. Crul, M.; Diehl, J.C.; Ryan, C. Design for Sustainability-A Step-by-Step Approach; UNEP: Paris, France, 2009.

52. Van Halen, C.; Vezzoli, C.; Wimmer, R. Methodology for Product Service System Innovation: How to Develop Clean, Clever and Competitive Strategies in Companies; Uitgeverij Van Gorcum: Assen, The Netherlands, 2005.

53. Kimita, K.; Shimomura, Y.; Arai, T. Evaluation of customer satisfaction for pss design. J. Manuf. Technol. Manag. 2009, 20, 654-673. [CrossRef]

54. Tasaki, T.; Hashimoto, S.; Moriguchi, Y. A quantitative method to evaluate the level of material use in lease/reuse systems of electrical and electronic equipment. J. Clean. Prod. 2006, 14, 1519-1528. [CrossRef] 
55. Lee, S.; Geum, Y.; Lee, H.; Park, Y. Dynamic and multidimensional measurement of product-service system (pss) sustainability: A triple bottom line (tbl)-based system dynamics approach. J. Clean. Prod. 2012, 32, 173-182. [CrossRef]

56. Hu, H.A.; Chen, S.; Hsu, C.; Wang, C.; Wu, C. Development of sustainability evaluation model for implementing product service systems. Int. J. Environ. Sci. Technol. 2012, 9, 343-354.

57. Xing, K.; Wang, H.-F.; Qian, W. A sustainability-oriented multi-dimensional value assessment model for product-service development. Int. J. Prod. Res. 2013, 51, 5908-5933. [CrossRef]

58. Rexfelt, O; Hiort af Ornäs, V. Consumer acceptance of product-service systems: Designing for relative advantages and uncertainty reductions. J. Manuf. Technol. Manag. 2009, 20, 674-699. [CrossRef]

59. Barquet, A.P.B.; de Oliveira, M.G.; Amigo, C.R.; Cunha, V.P.; Rozenfeld, H. Employing the business model concept to support the adoption of product-service systems (pss). Ind. Market. Manag. 2013, 42, 693-704. [CrossRef]

60. Belvedere, V.; Grando, A.; Bielli, P. A quantitative investigation of the role of information and communication technologies in the implementation of a product-service system. Int. J. Prod. Res. 2013, 51, 410-426. [CrossRef]

61. Barras, R. Towards a theory of innovation in services. Res. Pol. 1986, 15, 161-173. [CrossRef]

62. Bitner, M.J.; Brown, S.W.; Meuter, M.L. Technology infusion in service encounters. J. Acad. Marke. Sci. 2000, 28, 138-149. [CrossRef]

63. Lelah, A.; Brissaud, D. Clarifying frontiers of PSS and information and communication technologies. The Philosopher's Stone for Sustainability; Springer: Berlin/Heidelberg, Germany, 2013; pp. 441-446.

64. Geum, Y.; Lee, S.; Kang, D.; Park, Y. Technology roadmapping for technology-based product-service integration: A case study. J. Eng. Technol. Manag. 2011, 28, 128-146. [CrossRef]

65. Schmuntzsch, U.; Feldhaus, L.H. The warning glove: Wearable computing technology for maintenance assistance in ips2. IFAC Proc. Volum. 2013, 46, 70-75. [CrossRef]

66. Shih, L.-H.; Lee, Y.-T.; Huarng, F. Creating customer value for product service systems by incorporating internet of things technology. Sustainability 2016, 8, 1217. [CrossRef]

67. Griffiths, T.L.; Steyvers, M. Finding scientific topics. Proc. Nat. Acad. Sci. 2004, 101, 5228-5235. [CrossRef] [PubMed]

(C) 2018 by the authors. Licensee MDPI, Basel, Switzerland. This article is an open access article distributed under the terms and conditions of the Creative Commons Attribution (CC BY) license (http:/ / creativecommons.org/licenses/by/4.0/). 